DOI 10.15593/2224-9354/2018.2.14

УДК 330.341(470.53)

\author{
Т.В. Алферова, Е.А. Третьякова
}

\author{
ОПРЕДЕЛЕНИЕ ТЕНДЕНЦИЙ \\ СОЦИАЛЬНО-ЭКОНОМИЧЕСКОГО РАЗВИТИЯ \\ ЭКОНОМИКИ ПЕРМСКОГО КРАЯ
}

Проведен анализ ключевых социально-экономических показателей Пермского края за период с 2005 по 2016 год и выявлены факторы, влияющие на их динамику. Целью исследования является определение вектора социально-экономического развития экономики Пермского края. Методический инструментарий: системный, логический и статистический методы - для анализа официальной информации о национальной и региональной социально-экономических системах; методы экономического анализа - для расчета эффективности использования основных фондов и трудовых ресурсов. Ключевым выводом исследования является наглядное отражение того, что промышленный сектор экономики Пермского края характеризуется ежегодным повышением производительности труда при высокой степени износа основных фондов, на фоне низких темпов роста реальной заработной платы, что свидетельствует об ориентированности рынка труда Пермского края на политику эксплуатации трудовых ресурсов. К основным результатам работы можно отнести расчет и анализ динамики показателей зарплатоотдачи, капиталоотдачи и фондовооруженности, на основании чего подтвержден вывод о том, что на величину совокупного продукта, создаваемого в процессе производства, наибольшее влияние в Пермском крае оказывает потребление трудовых ресурсов. Новизна работы состоит в аргументированном определении вектора развития экономики региона, основанном на экономическом анализе и сопоставлении его результатов со статистическими данными. Полученные результаты целесообразно учитывать при формировании концепции социально-экономического развития региона, поскольку при сохранении такой структуры производства для дальнейшего роста экономики Пермского края необходима ориентация на социальную политику, включающую воспроизводство трудовых ресурсов: повышение реальной заработной платы, улучшение условий труда, качества жизни, снижение миграционного оттока, повышение численности населения и пр.

Ключевые слова: производительность труда, заработная плата, зарплатоотдача, фондовооруженность, капиталоотдача, основные фонды, численность населения, Пермский край.

Введение. Пермский край - регион с высоким природным, культурным и экономическим потенциалом, основную долю которого занимает промышленный комплекс, включающий нефтяную, химическую и нефтехимическую промышленность, черную и цветную металлургию, машиностроение, лесопромышленный комплекс и другие отрасли. Все это составляет хорошую основу для развития экономики региона, однако в последние годы наблюдается снижение одних социально-экономических показателей, например численности

(C) Алферова Т.В., Третьякова Е.А., 2018

Алферова Татьяна Викторовна - канд. экон. наук, доцент кафедры «Менеджмент» ФГБОУ ВО «Пермский государственный национальный исследовательский университет», e-mail: talferova68@mail.ru.

Третьякова Елена Андреевна - д-р экон. наук, профессор кафедры «Мировая и региональная экономика, экономическая теория» ФГБОУ ВО «Пермский государственный национальный исследовательский университет», e-mail: E.A.T.pnrpu@yandex.ru. 
экономически активного населения региона, численности занятых, и одновременный рост других показателей, например индекса промышленного производства и пр. Исходя из этого целью исследования является определение тенденций социально-экономического развития экономики Пермского края и выявление факторов, в наибольшей степени обеспечивающих это развитие. Данная цель формирует новизну работы, состоящую в аргументированном определении вектора развития экономики региона, основанном на экономическом анализе и сопоставлении его результатов со статистическими данными.

Исследуемому вопросу посвящены труды [1-6], касающиеся различных аспектов эффективности использования региональных ресурсов, в том числе трудовых, однако в условиях крайне высокой динамичности экономических и других процессов необходим постоянный мониторинг существующих тенденций с использованием новых, все более точных инструментов исследования.

Ориентированность промышленного сектора экономики Пермского края на эксплуатацию ресурса труда. Начиная с 2015 года наблюдается снижение численности населения Пермского края, что может быть обусловлено как падением естественного прироста, так и повышением миграционного оттока (табл. 1). По данным Пермьстата [7], чаще всего жители края выезжали на постоянное место жительства за пределы Приволжского федерального округа в Москву, Санкт-Петербург, Краснодарский край, Екатеринбург и Московскую область. Численность занятых в экономике Пермского края также имела тенденцию к снижению и составляла в среднем 99,3 \% ежегодно. В целом по стране темп роста занятых за исследуемый период сохранял тенденцию к незначительному ежегодному росту и составил в среднем 100,5 \% [8].

Таблица 1

Основные социально-экономические показатели Пермского края за 2012-2016 годы [9]

\begin{tabular}{|l|c|c|c|c|c|c|}
\hline \multicolumn{1}{|c|}{ Показатель } & 2012 & 2013 & 2014 & 2015 & 2016 & $\begin{array}{c}\text { Среднего- } \\
\text { довой темп } \\
\text { изменения, } \\
\%\end{array}$ \\
\hline $\begin{array}{l}\text { Численность населения } \\
\text { (на конец года), тыс. чел. }\end{array}$ & 2634,5 & 2636,2 & 2637,0 & 2634,4 & 2632,1 & 100,0 \\
\hline $\begin{array}{l}\text { Естественный прирост, } \\
\text { убыль населения, чел. }\end{array}$ & 1478 & 1671 & 1936 & 1391 & 889 & 88,1 \\
\hline $\begin{array}{l}\text { Миграционный прирост, } \\
\text { убыль населения, чел. }\end{array}$ & 1910 & 22 & -1058 & -4014 & -3201 & - \\
\hline $\begin{array}{l}\text { Численность занятых } \\
\text { в экономике, тыс. чел. }\end{array}$ & 1272,7 & 1250,2 & 1209,0 & 1223,0 & 1236,7 & 99,3 \\
\hline $\begin{array}{l}\text { Численность безработных, } \\
\text { тыс. чел. }\end{array}$ & 84,9 & 86,6 & 74,8 & 81,7 & 76,5 & 97,4 \\
\hline
\end{tabular}


Окончание табл. 1

\begin{tabular}{|c|c|c|c|c|c|c|}
\hline Показатель & 2012 & 2013 & 2014 & 2015 & 2016 & $\begin{array}{l}\text { Среднего- } \\
\text { довой темп } \\
\text { изменения, } \\
\text { \% }\end{array}$ \\
\hline $\begin{array}{l}\text { Численность пенсионеров, } \\
\text { тыс. чел. }\end{array}$ & 768,5 & 776,8 & 783,9 & 789,4 & 793,5 & 100,8 \\
\hline $\begin{array}{l}\text { Среднедушевые денежные } \\
\text { доходы населения, руб. } \\
\text { в месяц }\end{array}$ & 23328,8 & 26054,3 & 28315,5 & 32042,6 & 28725,8 & 105,3 \\
\hline $\begin{array}{l}\text { Среднемесячная номиналь- } \\
\text { ная начисленная заработная } \\
\text { плата работников организа- } \\
\text { ций, руб. }\end{array}$ & 21820,9 & 24715,5 & 27102,3 & 28527,9 & 30713,3 & 108,9 \\
\hline $\begin{array}{l}\text { Валовой региональный } \\
\text { продукт (валовая добавлен- } \\
\text { ная стоимость), в текущих } \\
\text { основных ценах: }\end{array}$ & & & & & & \\
\hline всего, млрд руб. & 860,3 & 880,3 & 974,2 & 1048,0 & $\mathrm{H} /$ Д & 106,8 \\
\hline на душу населения, тыс. руб. & 326,8 & 334,0 & 369,5 & 397,6 & н/Д & 106,8 \\
\hline $\begin{array}{l}\text { Сальдированный финансо- } \\
\text { вый результат организаций, } \\
\text { млрд руб. }\end{array}$ & 186,8 & 144,5 & 111,1 & 176,5 & 205,3 & 102,4 \\
\hline $\begin{array}{l}\text { Инвестиции в основной } \\
\text { капитал, млрд руб. }\end{array}$ & 162,2 & 219,5 & 207,6 & 226,2 & 237,0 & 109,9 \\
\hline $\begin{array}{l}\text { Основные фонды } \\
\text { (на конец года по полной } \\
\text { учетной стоимости), млн руб. }\end{array}$ & 2199176 & 2410614 & 2651647 & 2900859 & н/д & 109,7 \\
\hline $\begin{array}{l}\text { Коэффициент обновления } \\
\text { основных фондов, \% }\end{array}$ & 6,5 & 6,1 & 5,9 & 7,0 & $\mathrm{H} /$ д & - \\
\hline $\begin{array}{l}\text { Коэффициент выбытия } \\
\text { основных фондов, \% }\end{array}$ & 0,6 & 0,5 & 0,6 & 0,5 & $\mathrm{H} /$ Д & - \\
\hline $\begin{array}{l}\text { Степень износа основных } \\
\text { фондов, \% }\end{array}$ & 61,8 & 62,9 & 63,6 & 63,7 & $\mathrm{H} /$ д & - \\
\hline $\begin{array}{l}\text { Индекс потребительских цен } \\
\text { (декабрь к декабрю преды- } \\
\text { дущего года), \% }\end{array}$ & 107,3 & 106,5 & 110,4 & 112,6 & 105,4 & - \\
\hline $\begin{array}{l}\text { Внешнеторговый оборот, } \\
\text { млн долл. США, в том числе: }\end{array}$ & 8886,6 & 8079,1 & 8714,1 & 7028,1 & 4892,4 & 86,1 \\
\hline экспорт & 7991,2 & 6991,8 & 7642,9 & 6355,7 & 4181,3 & 85,1 \\
\hline импорт & 895,5 & 1087,3 & 1071,3 & 672,3 & 711,1 & 94,4 \\
\hline
\end{tabular}

Аналогичная тенденция характерна для всего Приволжского федерального округа, где среднегодовой прирост составляет 0,1% [8] (табл. 2).

Одновременно с численностью занятых ежегодно снижалась и численность безработных, что может быть обусловлено миграционным оттоком населения трудоспособного возраста. В результате чего увеличилась доля пен- 
сионеров в общей численности населения с 29 \% в 2012 году до $30 \%$ в 2016 году, вследствие этого повысилась демографическая нагрузка на работающее население.

Таблица 2

Численность занятых, в среднем за год, в 2005-2016 годах, тыс. чел. [8]

\begin{tabular}{|c|c|c|c|}
\hline Год & $\begin{array}{c}\text { Российская } \\
\text { Федерация }\end{array}$ & $\begin{array}{c}\text { Приволжский } \\
\text { федеральный округ }\end{array}$ & Пермский край \\
\hline 2005 & 68339,0 & 14536,5 & 1278,6 \\
\hline 2006 & 69168,7 & 14733,6 & 1318,3 \\
\hline 2007 & 70770,3 & 14888,1 & 1313,5 \\
\hline 2008 & 71003,1 & 14834,8 & 1293,9 \\
\hline 2009 & 69410,5 & 14530,8 & 1273,7 \\
\hline 2010 & 69933,7 & 14664,5 & 1285,7 \\
\hline 2011 & 70856,6 & 14800,8 & 1287,2 \\
\hline 2012 & 71545,4 & 14883,2 & 1272,7 \\
\hline 2013 & 71391,5 & 14838,2 & 1250,2 \\
\hline 2014 & 71539,0 & 14812,3 & 1209,0 \\
\hline 2015 & 72323,6 & 14759,0 & 1223,0 \\
\hline 2016 & 72392,6 & 14710,4 & 1236,7 \\
\hline Изменение & 100,5 & 100,1 & 99,7 \\
\hline за период, \% & & & \\
\hline
\end{tabular}

В качестве положительной динамики можно отметить рост валового регионального продукта в среднем на $2,4 \%$ ежегодно, однако в 2016 году наблюдалось снижение внешнеторгового финансового оборота, в то время как экономика Пермского края носит экспортоориентированный характер, при этом значительную долю добавленной стоимости формируют добыча и переработка нефти, а также химическое производство [10].

Достаточными темпами по сравнению с прочими показателями росли инвестиции в основной капитал (на $10,9 \%$ ежегодно) и основные фонды $(9,6 \%)$. Однако степень износа основных фондов по-прежнему осталась достаточно высокой (более $60 \%$ ).

В течение пяти последних лет в среднем на 8,9 \% ежегодно повышалась среднемесячная номинальная начисленная заработная плата. Анализ тех же показателей, но взятых за более длительный период (с 2005 по 2015 год) и в сопоставимых ценах позволил уточнить сделанные ранее выводы. Так, среднегодовой темп роста среднемесячной номинальной начисленной заработной платы в Пермском крае составил 114 \% при 115 \% по Российской Федерации, а с учетом индекса потребительских цен всего 103 и 105,7 \% соответственно (рис. 1, 2). При этом производительность труда, рассчитанная как отношение выпуска продукции, товаров и услуг к среднесписочной числен- 
ности занятых, стабильно повышалась (рис. 3), составляя ежегодный прирост в среднем на 10 \% по Пермскому краю и 11 \% по Российской Федерации.

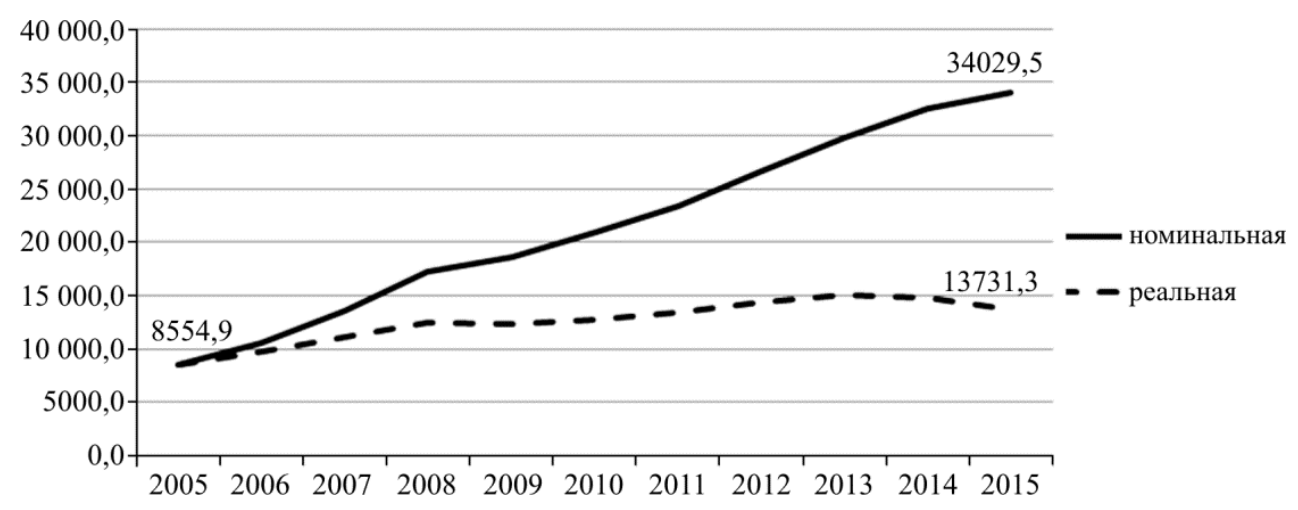

Рис. 1. Среднемесячная начисленная заработная плата работников организаций в Российской Федерации в 2005-2015 годах, руб.

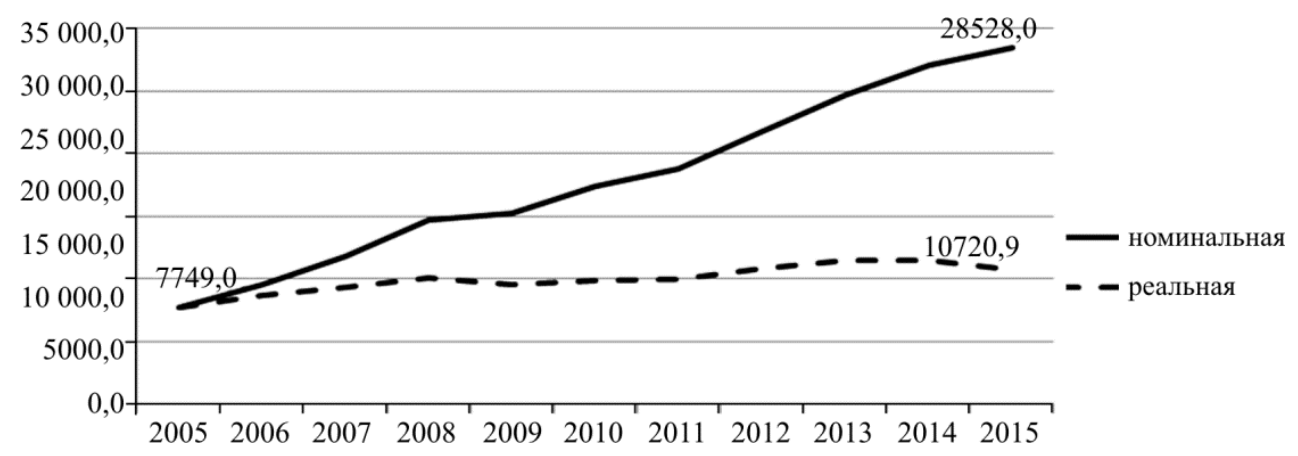

Рис. 2. Среднемесячная начисленная заработная плата работников организаций в Пермском крае в 2005-2015 годах, руб.

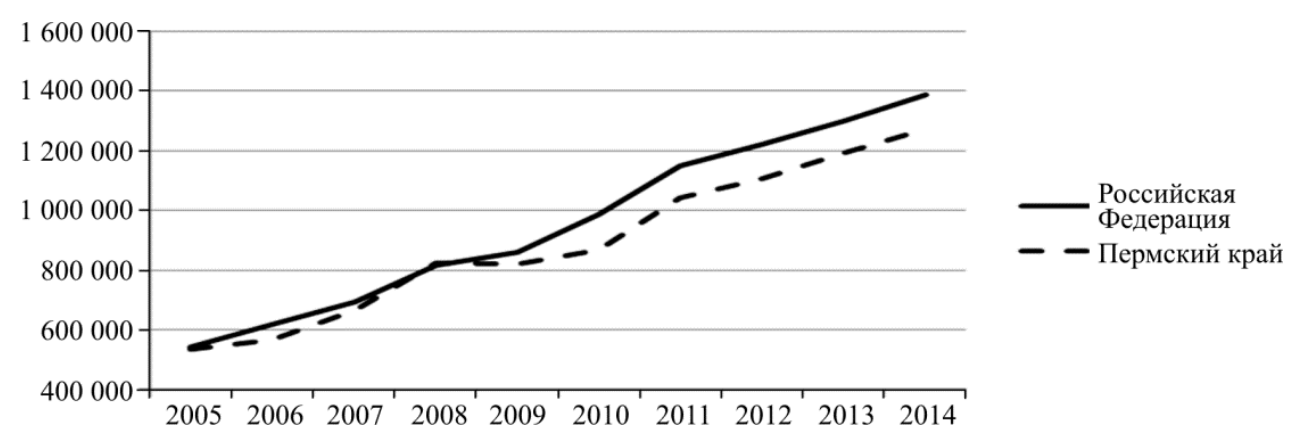

Рис. 3. Производительность труда в 2005-2014 годах, руб.

Соотнесение темпов изменения среднемесячной начисленной заработной платы и производительности труда в сопоставимых ценах показывает их сущест- 
венный дисбаланс (рис. 4, 5), демонстрируя ориентированность рынка труда на политику эксплуатации трудовых ресурсов, как в регионе, так и в стране в целом.

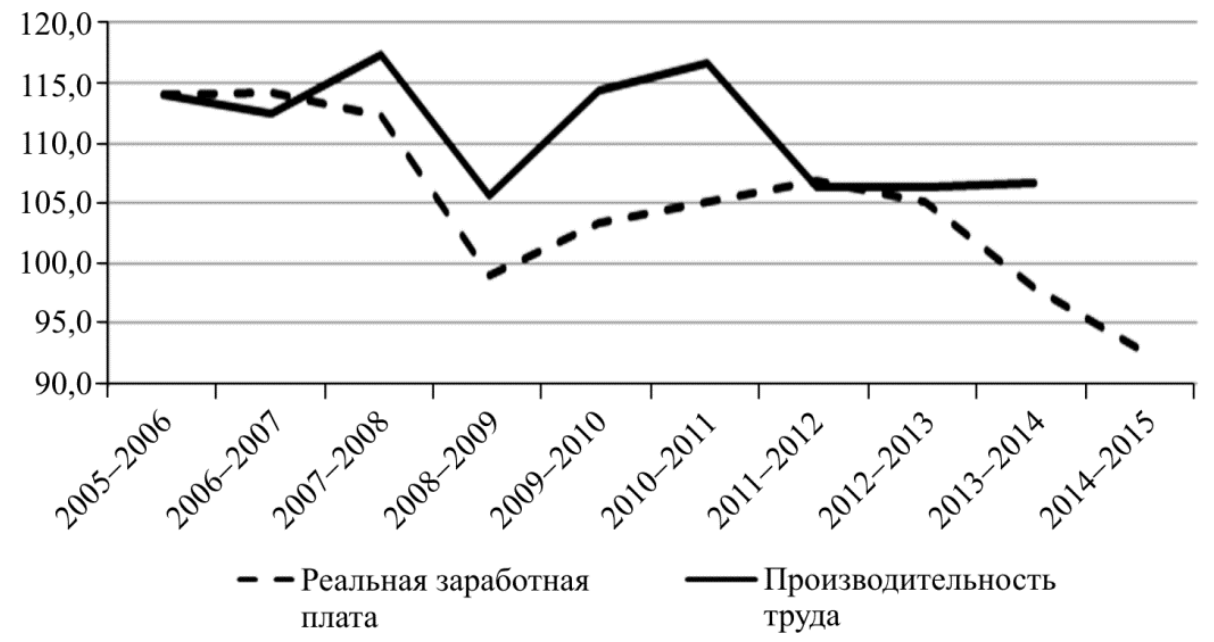

Рис. 4. Темпы изменения среднемесячной реальной заработной платы и производительности труда в Российской Федерации в 2005-2015 годах, \%

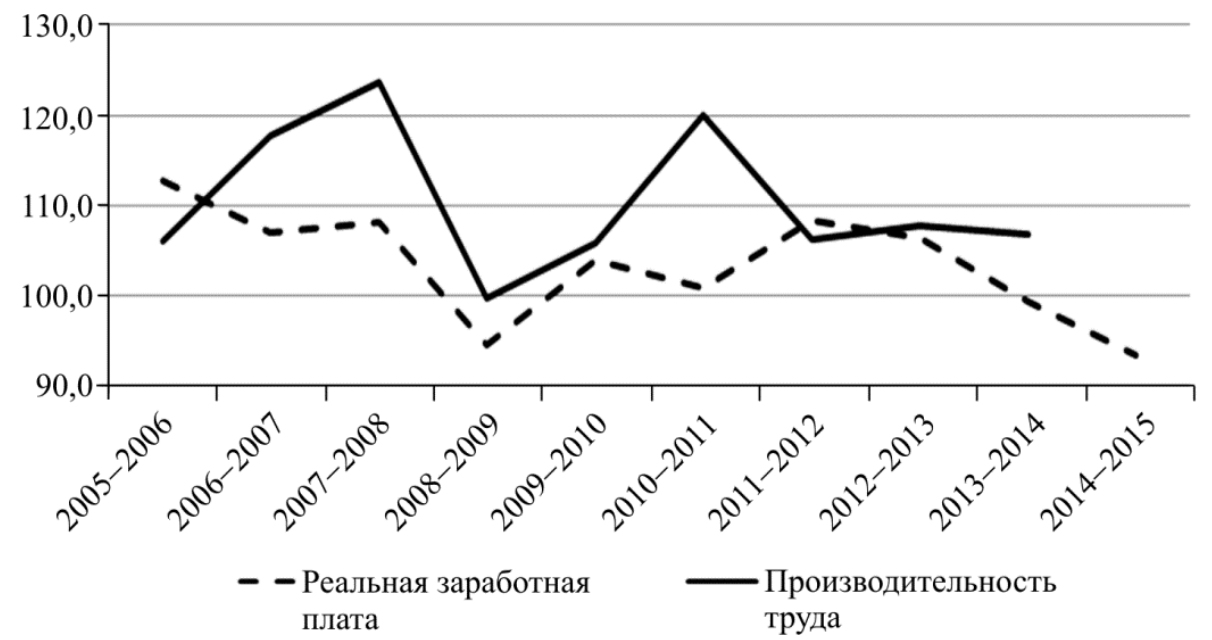

Рис. 5. Темпы изменения среднемесячной реальной заработной платы и производительности труда в Пермском крае в 2005-2015 годах, \%

Данная тенденция подтверждается ростом экономической отдачи затрат на оплату труда (рис. 6), которая в Пермском крае на протяжении всего исследуемого периода была выше, чем в целом по стране. Например, в 2005 году на 1 руб. заработной платы в Российской Федерации приходилось 5,2 руб. произведенной продукции, а в Пермском крае - 5,7 руб. В 2014 году в России эта цифра составила 7,8 руб., а в Пермском крае - уже 9,2 руб. 


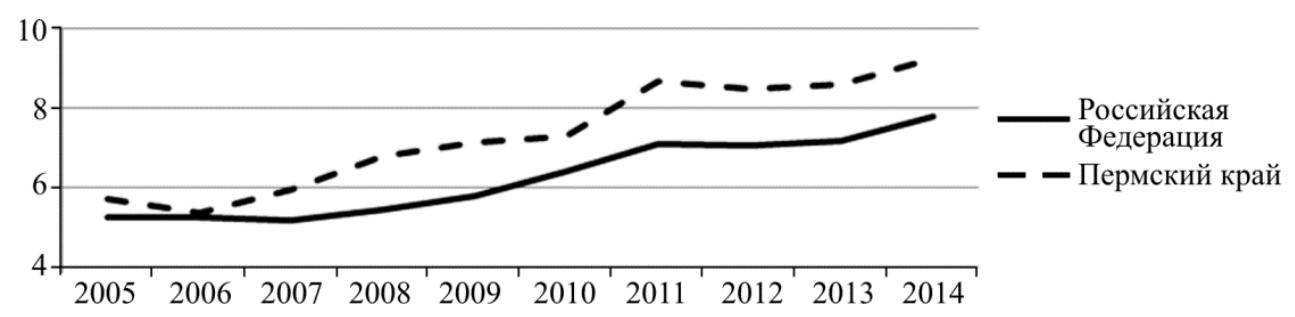

Рис. 6. Динамика зарплатоотдачи в 2005-2014 годах, руб.

Эффективность использования основного капитала, напротив, в Пермском крае значительно ниже, чем в целом по стране (рис. 7). Так, в исследуемом периоде на 1 руб. капитала, в среднем приходилось лишь 0,79 руб. произведенной продукции (при 0,96 руб. по Российской Федерации), что также свидетельствует о том, что экономический рост в регионе достигается в основном за счет ресурса труда, а не капитала.

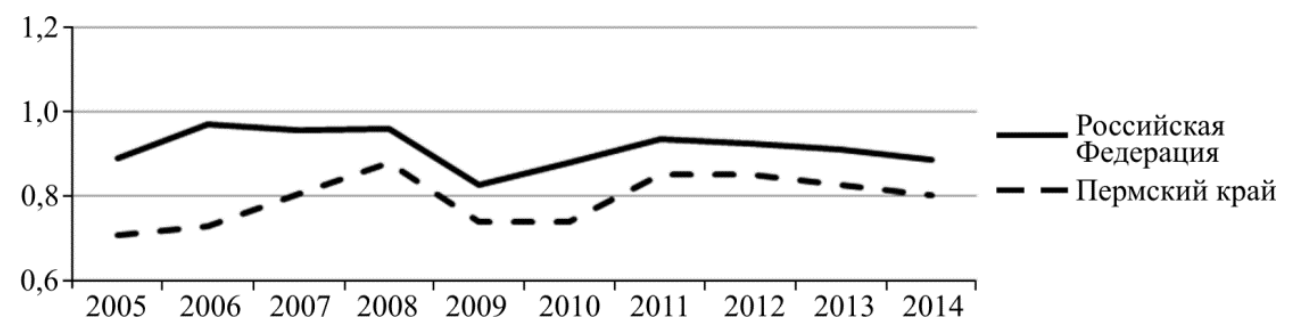

Рис. 7. Динамика капиталоотдачи в 2005-2014 годах, руб.

Аналогичный вывод следует и из динамики фондовооруженности (рис. 8), которая в 2005 году в регионе была даже выше, чем в среднем по стране, однако к 2014 году Пермский край утратил это преимущество.

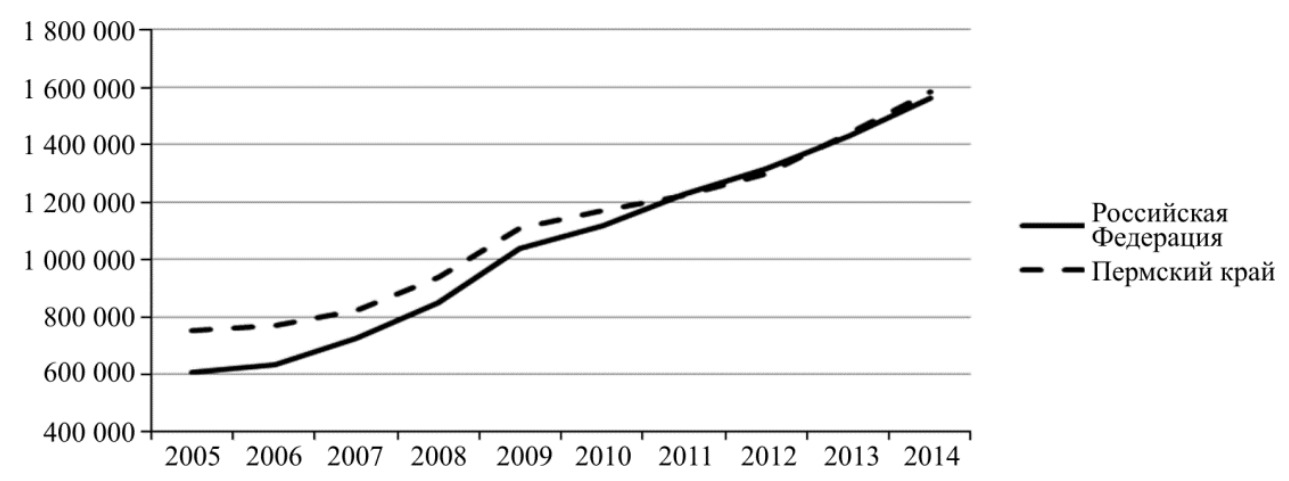

Рис. 8. Динамика фондовооруженности в 2005-2014 годах, руб.

Все вышеизложенное свидетельствует о негативных тенденциях, способных повлиять на ожидаемые итоги социально-экономического развития Пермского края за истекший год и в дальнейшей перспективе. 
Bbыводы. Промышленный сектор экономики Пермского края характеризуется ежегодным повышением производительности труда при высокой степени износа основных фондов, на фоне общего снижения показателя капиталоотдачи. В то же время наблюдается рост производственных показателей. Так, в 2017 году индекс промышленного производства увеличился на 2,9 \% к январю-июлю 2016 года [10]. Следовательно, на величину совокупного продукта, создаваемого в процессе производства, наибольшее влияние в Пермском крае оказывает потребление трудовых ресурсов, что подтверждается положительной динамикой показателя зарплатоотдачи. Такое положение дел в промышленном секторе экономики характерно для всех старопромышленных регионов России, к которым относится и Пермский край, где рост производительности труда достигается на устаревшей производственной базе, часто не позволяющей автоматизировать многие трудоемкие процессы [5]. При сохранении такой структуры производства для дальнейшего роста экономики Пермского края важна ориентация на социальную политику, включающую в себя воспроизводство трудовых ресурсов, повышение реальной заработной платы, улучшение условий труда, снижение миграционного оттока, повышение численности населения. Полученные результаты и выводы следует принять во внимание не только при формировании концепции социально-экономического развития Пермского края, но и при подведении итогов степени продвижения к ее целевым показателям.

\section{Список литературы}

1. Алиев Р.И. Изменения ВРП и производительности труда Пермского края // Электронный мультидисциплинарный научный журнал с порталом международных научно-практических конференций «Интернетнаука». 2015. - № 11. - C. 106-113. - URL: https://internetnauka.ru/index.php/journal (дата обращения: 18.12.2017).

2. Антипьев К.А. Проблемы трудовой миграции в Пермском крае // Историческая и социально-образовательная мысль. - 2012. - № 4(14). - С. 151-152.

3. Конкурентоспособность и управление развитием национальной и региональной экономики: синтез иерархического и институционального анализа / Е.В. Базуева, Е.Е. Жуланов, Т.В. Карлина, Т.Ю. Ковалева, Т.В. Миролюбова, Д.Н. Шульц // Вестник Пермского университета. Экономика. - 2016. № 1 (28). - С. 7-40.

4. Миролюбова Т.В. Производительность труда в регионах России: пространственные аспекты и взаимосвязь с информационными ресурсами // Вестник Пермского университета. Экономика. - 2016. - № 3(30). - С. 120-131.

5. Проблемы развития промышленного сектора экономики старопромышленных регионов России / Т.В. Ускова, Е.В. Лукин, А.Е. Мельников, Е.Г. Леонидова // Экономические и социальные перемены: факты, тенденции, прогноз. - 2017. - Т. 10, № 4. - С. 62-77.

6. Царенко И.В. Состояние и перспективы эффективного использования трудовых ресурсов на примере Пермского края // Вестник Удмуртского университета. Экономика и право. - 2016. - № 1 (26). - С. 54-60. 
7. Территориальный орган Федеральной службы государственной статистики по Пермскому краю: офиц. сайт. - URL: http://permstat.gks.ru/wps/wcm/ connect/rosstat_ts/permstat/ru/statistics/ (дата обращения: 11.11.2017).

8. Федеральная служба государственной статистики: [сайт]. - URL: http://www.gks.ru (дата обращения: 09.11.2016).

9. Пермский край в цифрах: крат. стат. сб. / Территор. орган Федер. службы гос. статистики по Пермскому краю. - Пермь, 2017. - 180 с.

10. Предварительные итоги социально-экономического развития Пермского края за истекший период 2017 года и ожидаемые итоги социальноэкономического развития Пермского края за 2017 год [Электронный ресурс]. URL: http://mfin.permkrai.ru/upload/pages/2000/dat_1506949925364.pdf (дата обращения: 08.11.2017).

\section{References}

1. Aliev R.I. Izmeneniia VRP i proizvoditel'nosti truda Permskogo kraia [GRP and labour productivity changes of Perm Krai]. Electronic Interdisciplinary Scientific Journal INTERNETSCIENCE, 2015, no. 11, pp. 106-113, available at: https://internetnauka.ru/index.php/journal (accessed 18 December 2017).

2. Antip'ev K.A. Problemy trudovoi migratsii v Permskom krae [Problems of labour migration in the Perm region]. Historical and social-educational ideas, 2012, no. 4 (14), pp. 151-152.

3. Bazueva E.V., Zhulanov E.E., Karlina T.V. et al. Konkurentosposobnost' i upravlenie razvitiem natsional'noi i regional'noi ekonomiki: sintez ierarkhicheskogo i institutsional'nogo analiza [Competitiveness and management of the national and regional economy's development: synthesis of hierarchical and institutional analysis]. Perm University Herald. Economy, 2016, no. 1(28), pp. 7-40.

4. Miroliubova T.V. Proizvoditel'nost' truda $\mathrm{v}$ regionakh Rossii: prostranstvennye aspekty i vzaimosviaz' $\mathrm{s}$ informatsionnymi resursami [Labor productivity in Russian regions: spatial aspects and interrelation with information resources]. Perm University Herald. ECONOMY, 2016, no. 3(30), pp. 120-131.

5. Uskova T.V., Lukin E.V., Mel'nikov A.E. et al. Problemy razvitiia promyshlennogo sektora ekonomiki staropromyshlennykh regionov Rossii [Industrial development issues in the economy of the old industrial regions of Russia]. Economic and Social Changes: Facts, Trends, Forecast, 2017, vol. 10, no. 4, pp. 62-77.

6. Tsarenko I.V. Sostoianie i perspektivy effektivnogo ispol'zovaniia trudovykh resursov na primere Permskogo kraia [The state and the prospects of efficient utilization of labor resources by the example of Perm Krai]. Bulletin of Udmurt University. Series Economics and Law, 2016, no. 1 (26), pp. 54-60.

7. Territorial'nyi organ Federal'noi sluzhby gosudarstvennoi statistiki po Permskomu kraiu [Territorial body of the Federal State Statistics Service in Perm Krai. Official website], available at: http://permstat.gks.ru/wps/wcm/connect/ rosstat_ts/permstat/ru/statistics/ (accessed 9 November 2016).

8. Federal'naia sluzhba gosudarstvennoi statistiki [Federal State Statistics Service. Official website], available at: http://www.gks.ru (accessed 9 November 2016). 
9. Permskii krai v tsifrakh [Perm Krai in figures. A brief statistical compilation]. Perm, Federal State Statistics Service for Perm Krai, 2017, 180 p.

10. Predvaritel'nye itogi sotsial'no-ekonomicheskogo razvitiia Permskogo kraia za i stekshii period 2017 goda i ozhidaemye itogi sotsial'no-ekonomicheskogo razvitiia Permskogo kraia za 2017 god [Preliminary results of Perm Krai social and economic development for the past perio of 2017 and the expected results of social and economic development of Perm Krai for 2017], available at: http://mfin.permkrai.ru/upload/ pages/2000/dat_1506949925364.pdf (accessed 8 November 2017).

Оригинальность $86 \%$

Получено 15.01.2018 Принято 12.02.2018 Опубликовано 29.06.2018

T.V. Alferova, E.A. Tretyakova

\title{
DETERMINING SOCIAL AND ECONOMIC TRENDS OF PERM KRAI'S ECONOMIC DEVELOPMENT
}

\begin{abstract}
The main socio-economic indicators of the Perm Krai for the period from 2005 to 2016 are analyzed and the factors influencing their dynamics are revealed. The purpose of the study is to determine the socio-economic development vector of Perm Krai economy. Methodical tools are systemic, logical and statistical methods to analyze official information about national and regional socio-economic systems; economic analysis methods to calculate fixed assets and labor efficiency use. The key conclusion of the study is a clear reflection of the fact that the industrial sector of the Perm Krai economy is characterized by an annual increase in labor productivity with a high degree of depreciation of fixed assets, on the background of low real wage growth rates, which indicates the orientation of Perm labor market to labor resources exploitation policy. The main results of the work include calculation and analysis of labor costs return dynamics, return on capital and fixed assets per employee, which allows to conclude that the labor resources consumption has the greatest influence on the aggregate product value created in the process of production. The novelty of the work consists in a justified definition of the regional economy development vector, based on economic analysis and comparison of its results with statistical data. The obtained results should be taken into account when forming the concept of social and economic development of the region, since with the maintenance of such a production structure, for further growth of the Perm Krai economy, it is necessary to focus on social policy, including reproduction of labor resources: increase of real wages, improvement of working conditions, quality of life, migration outflow, population increase, etc.

Keywords: labor productivity, wages, labor costs return, fixed assets per employee, capital return, fixed assets, population, Perm Krai.
\end{abstract}

Tatyana V. Alferova - Candidate of Economic Sciences, Associate Professor, Department of Management, Perm State National Research University, e-mail: talferova68@mail.ru.

Elena A. Tretyakova - Doctor of Economic Sciences, Professor, Dept. of World and Regional Economics and Economic Theory, Perm State National Research University, e-mail: E.A.T.pnrpu@yandex.ru.

Received 15.01.2018 Accepted 12.02.2018 Published 29.06.2018 